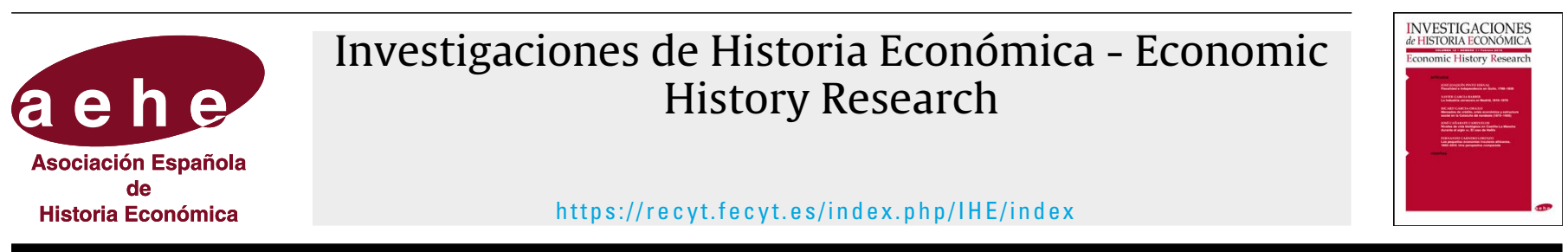

Artículo

\title{
Same place, different stories: The mortality burden of the 1918-1920 influenza pandemic in Denmark
}

\author{
Mathias Mølbak Ingholt* D \\ Roskilde University, Denmark
}

\section{Lone Simonsen $\mathbb{D}$}

Roskilde University, Denmark

\section{Maarten van Wijhe $\mathbb{D}$ \\ Roskilde University, Denmark}

\section{ARTICLE INFO}

\section{Article history:}

Reception: 5 junio 2020

Acceptance: 15 septiembre 2020

On-line: 1 diciembre 2020

\section{JEL classification:}

I140

N940

R100

N340

\section{Keywords}

Pandemic

Spanish flu

Excess mortality

Denmark

\section{Códigos JEL:}

I140

N940

R100

N340

Palabras clave:

Pandemia

Gripe española

Exceso de mortalidad

Dinamarca

\begin{abstract}
A B S T R A C T
The 1918-1920 Spanish influenza pandemic is iconic, leading in multiple waves to millions of deaths of mostly otherwise healthy young adults. In this paper, we study the pandemic's regional mortality burden in rural and urban Denmark. We find that 0,3\% of Denmark's population died during the four waves that constituted the pandemic. There were substantial regional differences with eastern Zealand being hit much harder than northern Jutland. Urbanization appears to have been an important discriminating factor behind influenza mortality, and the Spanish flu can be seen as an urban disease. On a regional scale, factors such as population density and access to medical care were not associated with increased influenza mortality while socioeconomic conditions were. We note that our study has limitations, and that other more local factors such as mitigation strategies, differing age-patterns and nutritional status may also explain the variances.
\end{abstract}

@ 2020 Asociación Española de Historia Económica

\section{Mismo lugar, historias diferentes: la carga de mortalidad de la pandemia de gripe española de 1918-1920 en Dinamarca}

\section{R E S U M E N}

La pandemia de gripe española de 1918-1920 es icónica y provocó a lo largo de múltiples oleadas la muerte de millones de adultos jóvenes sanos. En este artículo estudiamos la mortalidad regional en la Dinamarca rural y urbana. Estimamos que el 0,3\% de la población danesa murió durante las cuatro oleadas que constituyeron la pandemia. Hubo diferencias regionales sustanciales. Así, el impacto en el este de Selandia fue mucho mayor que en el norte de Jutlandia. La urbanización parece haber sido un factor discriminatorio importante tras la mortalidad por gripe, por lo que puede considerarse una enfermedad urbana. A escala regional, factores como la densidad poblacional y el acceso a la asistencia sanitaria no se asocian a una mayor mortalidad por gripe, mientras que las condiciones socioeconómicas sí. Reconocemos que nuestro estudio tiene limitaciones, y que otros factores locales como las estrategias de mitigación, la distribución por edad y el estado nutricional también podrían explicar estas variaciones.

\footnotetext{
* Corresponding author. Email: mingholt@ruc.dk
} 


\section{Introduction}

With 50 million deaths globally, the 1918-20 "Spanish flu" influenza pandemic remains one of the deadliest pandemics in modern history. The pandemic mortality burden in Denmark is still disputed. Estimates range from $0,2-0,4 \%$ of Denmark's population, corresponding to $\sim 6.000-13.000$ deaths (Table 1) (Medicinalberetning for den danske stat, 1919, 132133; Medicinalberetning for den danske stat, 1920, 105; Pat- terson and Pyle, 1991, 14; Murray et al., 2006; Andreasen et al., 2008; Kolte et al., 2008; Dahl et al., 2020). Most estimates have been made using urban data, and only two studies (Patterson and Pyle and Murray et al.) studied the mortality burden on national scale. A low estimate of $0,1 \%$ was based on excess mortality estimation from monthly data, while one estimate of $0,4 \%$ came from modeling detailed morbidity and mortality data from Copenhagen (Kolte et al., 2008; Andreasen et al., 2008). Table 1 reviews all available estimates.

\section{Table 1}

Previous estimates of the 1918-20 influenza pandemic mortality burden in Denmark

\begin{tabular}{|c|c|c|c|c|}
\hline Study & Year & Study population & Deaths & \% of study population \\
\hline Patterson and Pyle & 1991 & National & 11.400 & $0,4 \%$ \\
\hline Murray et al. & 2006 & National & $\sim 6.000$ & $0,2 \%$ \\
\hline Andreasen et al. & 2008 & Copenhagen & $\sim 2.200$ & $0,4 \%$ \\
\hline Dahl et al. & 2020 & $\begin{array}{l}\text { Copenhagen and province } \\
\text { towns }\end{array}$ & $4.150(1918)$ & 0,3\% (1918-1920) \\
\hline
\end{tabular}

Between countries, mortality patterns differ widely. Various authors have suggested several factors can explain variations in pandemic mortality. In a global modeling study, Denmark figured as the country with the lowest death toll of all measured countries (Murray et al., 2006). Within countries, geographical mortality variations have been reported in at least Newfoundland (Sattenspiel, 2011) and Denmark (Trier, 2018, 172, 200-208). Trier found that in Denmark, especially the town of Nakskov had been hit hard, while the neighboring towns were less affected. He also argued that rural communities may have been more affected than urban (ibid., 2018, 172, 200-208).

Although some have argued that Spanish flu mortality was randomly distributed without any connection to geography, economic development or climate, others disagreed (Dahl et al., 2020). Socioeconomic status has been found to be a risk factor in pandemic influenza outcomes with higher mortality among those of lower socioeconomic status (Mamelund, 2006; Bengtsson et al., 2018; Dahl et al., 2020). A global study found that both latitude and poverty were important predictors of excess mortality (Murray et al., 2006). A US study found an association between influenza mortality and illiteracy, infant mortality, and pollution (Clay et al., 2019). Mitigation strategies such as school closings and prohibiting public events were also important factors explaining mortality reductions (Hatchett et al., 2007; Markel, et al., 2007; Correia et al., 2020).

There is still much debate on what factors explain variability in mortality and morbidity during pandemics. Elucidating the role of various factors in historical pandemics such as the Spanish flu may shed light on why some populations and countries fare better and others worse in the 2019-2020 COVID-19 pandemic and any future pandemics. The ongoing SARS$\mathrm{CoV}-2$ virus holds the world in a tight grip and patterns of unequal mortality across regions are observed anew. Cities in northern Italy and New York City are examples of locations that have experienced high mortality in comparison with neighboring areas, and ethnic differences have been the topic of much debate. While most focus is on urban outbreaks, rural areas may face additional challenges due to insufficient access to healthcare and hygienic conditions (Zahnd, 2020; Sood and Sood, 2020). Drawing parallels between contemporary and historical pandemics is of course complex, but may still provide some insight into why such regional differences arise.

In this study, we take a look at the diverging morbidity and mortality burden of the 1918-20 Spanish flu influenza pandemic in rural and urban areas of Denmark. Additionally, we investigate the effect on excess mortality of factors such as urbanization, access to medical care, and socioeconomic conditions. Finally, we discuss other contributing factors, including local mitigation strategies, age-patterns, and nutrition. Given the limitations inherent to the available data, our aim was to provide an exploratory analysis.

This paper is organized as follows. Section 2 explores the regional morbidity patterns for influenza-like infections for 1918-1920. In this section, we also explore and discuss regional excess all-cause mortality and its relationship with the pandemic. In section 3 , we study the patterns with different geographic, medical and socioeconomic factors, and in section 4, we discuss other possible factors that could have contributed as well as our study's limitations.

\section{Regional patterns}

The pandemic took place decades before the discovery of the influenza virus, and influenza diagnosing took place based on symptom observation (Otto, 2002, 18). Due to the uncer- 


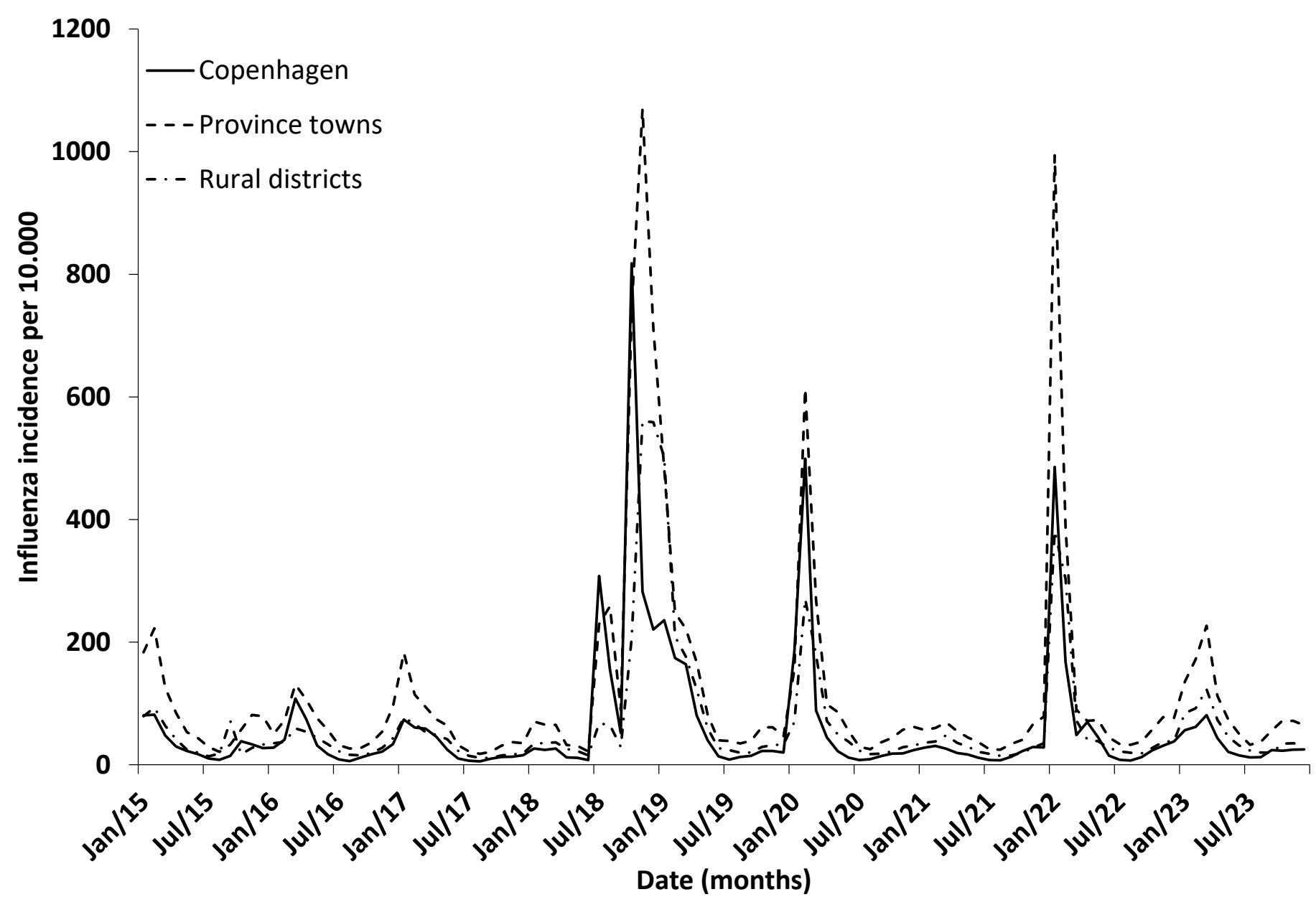

Figure 1. Monthly incidence of notified influenza cases per 10.000 population during the pandemic period 1915-1923, for Copenhagen, province towns and rural areas in Denmark with an estimated population for 1918.

Source: Medicinalberetning for den danske stat 1915-1923.

tainty in how an influenza diagnosis was made by the doctors and the association between influenza and pneumonia infections, the diagnoses "influenza", "pneumonia crouposa", "bronchopneumonia" and "tracheo-bronchitis" were combined in the analysis, and together termed "influenza-like" in the following sections. Already at the time, some doctors commented that other respiratory infections such as pneumonia and bronchitis were associated with pandemic influenza and should be considered together. ${ }^{1}$

\subsection{Rural and urban pandemic morbidity patterns}

The Spanish flu first broke out in Denmark in the second week of July 1918. Although the first identified cases were travelers from Norway and Germany, the pandemic's first major outbreak took place on a naval torpedo boat patrolling

\footnotetext{
${ }^{1}$ Danish National Archives, Sundhedsstyrelsens arkiv, Medicinalberetninger. Jylland: Randers Amtslægekreds, 1918, 15; Vejle Amtslægekreds, 1918, 26-34; Danish National Archives, Sundhedsstyrelsens arkiv, Medicinalberetninger. Øerne. Odense Amtslægekreds, 1918, 10. From here on out this archival cabinet will be referred to as "MB".
}

the Øresund strait (van Wijhe et al., 2018). Like some other countries in Europe, Denmark experienced a mild herald wave during the summer months, and a more lethal second and third wave during the fall and winter of 1918-1919 (Andreasen et al., 2008; Simonsen et al., 2018). A fourth wave peaked in February 1920 (Figure 1). During the first wave, the highest incidence of influenza morbidity seen by doctors occurred in the province towns and Copenhagen, while rural areas seemed to have mostly skipped the first wave. The second wave was larger and much deadlier, and it reached all regions of the country, affecting both the rural and urban populations. Interestingly, it appears that the province towns were apparently more severely affected than Copenhagen during the 2nd, 3rd and 4th waves (Figure 1 ). This was not only a pandemic phenomenon, but is also visible in terms of morbidity prior to and after the pandemic. Why this is the case is unclear and needs more detailed information on the local settings. During the second wave, influenza peaked in the province towns in November-December 1918 and December-January 1918-1919 in rural areas of Denmark (Kolte et al., 2008; Dahl et al., 2020). Interestingly, in 1922 influenza cases soared again, nearly reaching the same levels in 1918-1919, but it was much less deadly (Figure 2). 


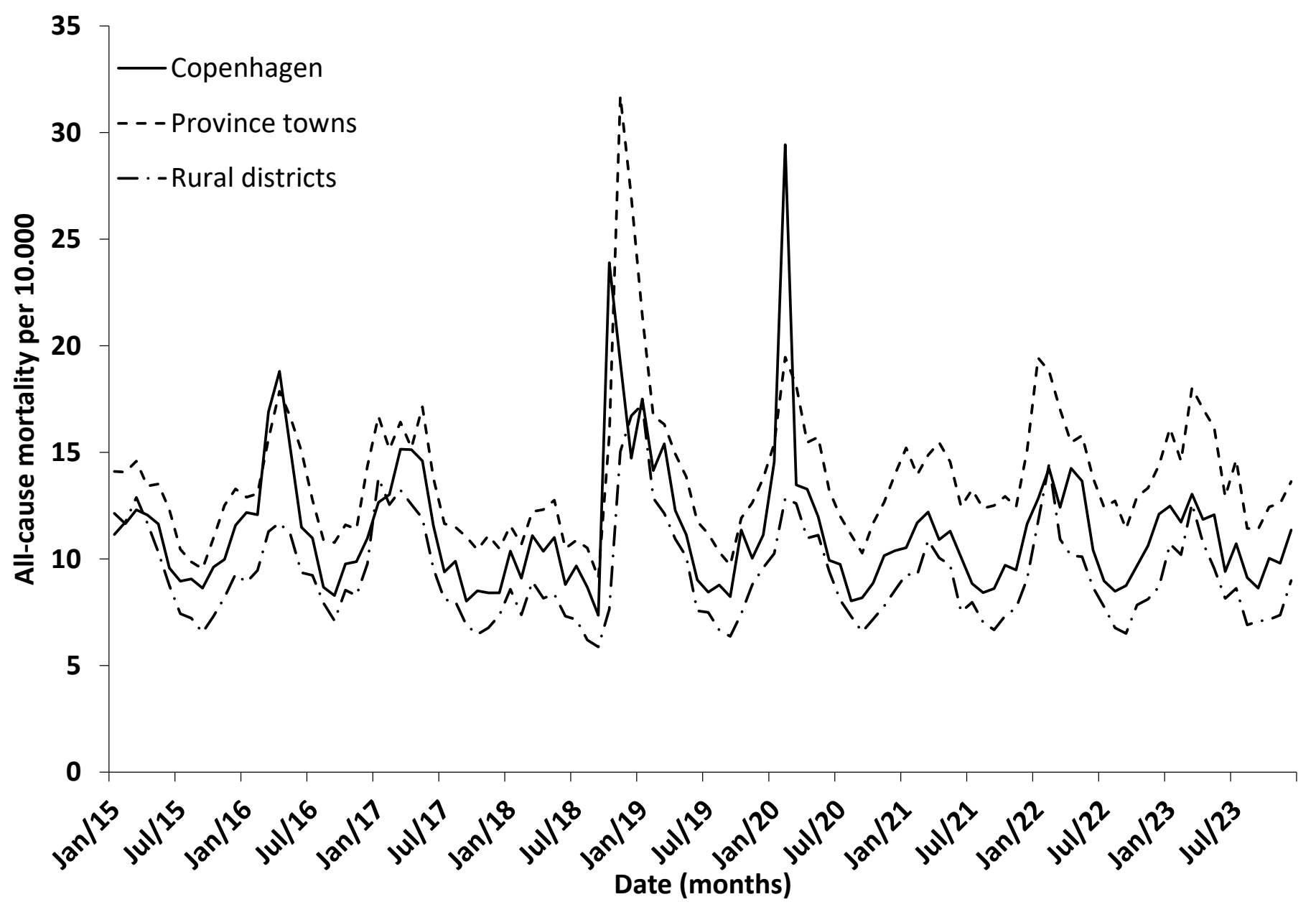

Figure 2. Monthly all-cause deaths per 10.000 inhabitants for the period 1915-1923 in Copenhagen (CPH), province towns, and rural areas in Denmark with an estimated population for 1918.

Source: Statistics Denmark: “Ægteskaber, Fødte og Døde” volumes 1911-1915, 1916-1920 and 1921-1925 and Medicinalberetning for den danske stat, 1918.

Mortality being higher in urban than rural areas during the Spanish flu reflects a general pattern from the 19th and early 20th centuries. ${ }^{2}$ Similarly, a study of 19 th century childhood mortality found that urbanization led to increasing childhood mortality (Løkke, 1998, 185-193). The importance of urbanization was something the chief medical officers took note of as well in 1918. Some noted local variations in mortality within the rural regions, showing that in some villages, death tolls were high, while in others, influenza-mortality was nearly absent. $^{3}$

At the time of the Spanish flu, the Danish healthcare system was divided into 21 medical regions ("amtslægekredse"). With the exception of two medical regions, the regions followed the administrative borders of the Danish counties ("amter"). The medical regions were composed of a number of districts ("lægekredse") that had urban province towns ("købstæder") and surrounding rural municipalities. The divisions between

\footnotetext{
2 Statistisk Tabelværk, 1905, 120-121.

${ }^{3}$ MB: Odense Amtslægekreds, 1918, 12-13; Thisted Amtslægekreds, 1918, 2-3.
}

Copenhagen, the province towns and rural areas, as used in the official statistics, were based on administrative choices. The province towns were defined as municipalities with traditionally certain economic activities such as crafting, that were not allowed outside. Rural areas constituted municipalities without a province town. According to the Danish census of 1916, $59 \%$ of the Danish population lived in areas classified as rural. ${ }^{4}$

Except for Århus and Odense, the Danish medical regions' borders followed those of the counties and incidence and excess deaths are comparable between the two. The regions of Århus and Odense were split in two medical regions each: Århus and Skanderborg, and Odense and Assens. Influenza incidence in 1918-1920 per 10.000 inhabitants was lowest in the rural and highest in the urban areas (Figure 1, Table 2, Figure 3 and supplementary Table 1 ). While the highest urban influenza incidence occurred in Assens on Fuenen, the highest rural influenza-like incidence was in the areas surrounding Copenhagen and Århus, the two largest cities in Denmark

${ }^{4}$ Statistics Denmark, Statistisk Tabelværk, Rk. 5. Litra A ; Nr. 14. Census of 1916 
Table 2

Total influenza-like cases for 1918-1920

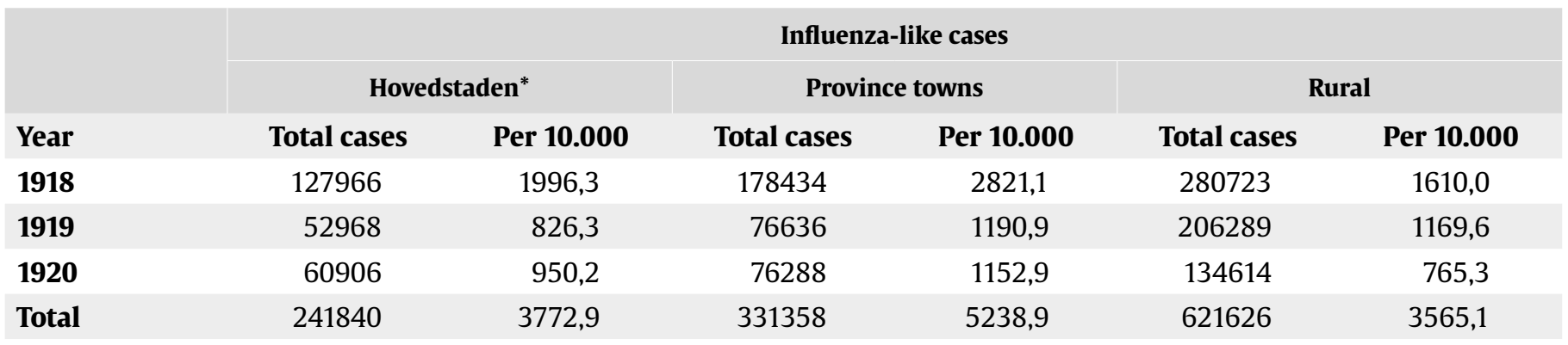

${ }^{*}$ Copenhagen, Frederiksberg and Gentofte.

Source: Medicinalberetning for den danske stat 1918-1920.

(supplementary Table 1). In Ålborg, the 3rd largest Danish city at the time, the influenza pandemic had a limited impact. While the number of cases suggest that influenza diffused from the larger cities into their surrounding rural areas, this was clearly not always the case.

\subsection{Rural and urban excess mortality patterns}

Respiratory mortality data exists for the Danish province towns, but not for rural areas. For this reason, and due to the risk of deaths being misdiagnosed, all-cause mortality data in the Danish counties were selected in the study of the mortality burden for the purpose of computing the excess mortality attributable to the pandemic. This data was published by Statistics Denmark in summary tables containing annual births, deaths and marriages. Two datasets were used for all-cause mortality, one with aggregated data on a monthly basis for Copenhagen, provincial towns, and rural areas, each stratified by sex, and another where the separate areas were stratified by each specific region. For the latter, only annual data was available. Each source thus provides different information, the first with a higher temporal resolution, the other with a higher spatial resolution. Following the method of Murray (2006), a baseline of average expected deaths was established both for the monthly data and for the annual data. For the annual data this consisted of the simple average of annual deaths by region from 1915-1917 and 1921-1923, and for the monthly data, the average monthly mortality was used. Thus the baseline for January 1919 was the average of the all-cause mortality in January 1915-1917 and 1921-1923. Excess mortalities were calculated as the difference between the annual or monthly all-cause mortality in 1918-1920 above this baseline.

All-cause mortality was lowest in the rural areas (Figure 2). There was a clear pattern in each region of later winter and early spring peaks, generally peaking around March and April. The pandemic stands out with an increased number of deaths starting in October 1918 for Copenhagen, and November 1918 for the province towns and rural areas. There was no discernable difference between male and female mortality (supplementary Figure 1). In addition, all regions seemed to have a very mild winter and spring mortality in early 1918 , and the 1918 pandemic itself does not stand out as much for rural regions compared to Copenhagen and the province towns. The normal mortality pattern seemed to resume in province towns and rural districts after the third wave of the pandemic had ended. In Copenhagen there was a distinct 4th wave in mortality early 1920 . Why the 4 th wave primarily affected Copenhagen is unclear. Excess mortality was also lower in rural areas than in urban areas in the epidemic years.

In the province towns, a total of 2.904 excess deaths occurred during the four pandemic waves. In rural areas, while absolute excess mortality was generally higher than province towns relative to the population, mortality was about half that of provincial towns and much lower than in Copenhagen. It should be noted that the second pandemic wave first broke out in the rural areas with a month's delay in the winter of 1919 (Figure 1 and Figure 2). It is likely that it took time for the pandemic to travel from the towns to the rural areas, but this cannot be said with certainty with this data. The estimate of the total number of excess deaths during the pandemic in Denmark is 10.184 , corresponding to $0,34 \%$ of Denmark's population. In urban areas this was $0,46 \%$ whereas in rural areas it was only $0,22 \%$. This distinction between urban and rural areas shows that overall mortality may be overestimated when solely based on information from urban areas.

Interestingly, excess mortality calculation based on annual mortality grossly underestimates the pandemic impact. We estimated $0,19 \%$ excess mortality using annual data-in agreement with the $0,2 \%$ estimated by Murray et al., (2006)-while the monthly pandemic specific mortality was $0,34 \%$ (Table 3 ). The generally higher winter mortality is spread over two separate years when using annual data, which may further mask nuances in mortality. The two calculations show the large discrepancy between estimates based on annual and monthly all-cause mortality.

A previous study using weekly mortality data for Copenhagen pointed out that estimates of excess mortality based on annual mortality may indeed underestimate pandemic mortality: Denmark experienced low mortality in spring of 1918 relative to the surrounding years, as can also be seen in Figure 2 (Andreasen and Simonsen 2011). It has been suggested that this was due to an increased mortality among elderly in 1916 and 1917, or dietary changes during World War I resulting in less meat and alcohol consumption (id.). It should be noted that social conditions during World War I were poor; prices on food and fuel were higher, taxes increased, and unemployment grew reaching $25 \%$ in the winter of 1917 , all of which had a negative impact on people's life courses (Hansen and Henriksen, 1984, 31-32, 74-78; Trier, 2018, 228-229). 
Table 3

Total excess deaths for 1918-1920 based on annual and monthly mortality

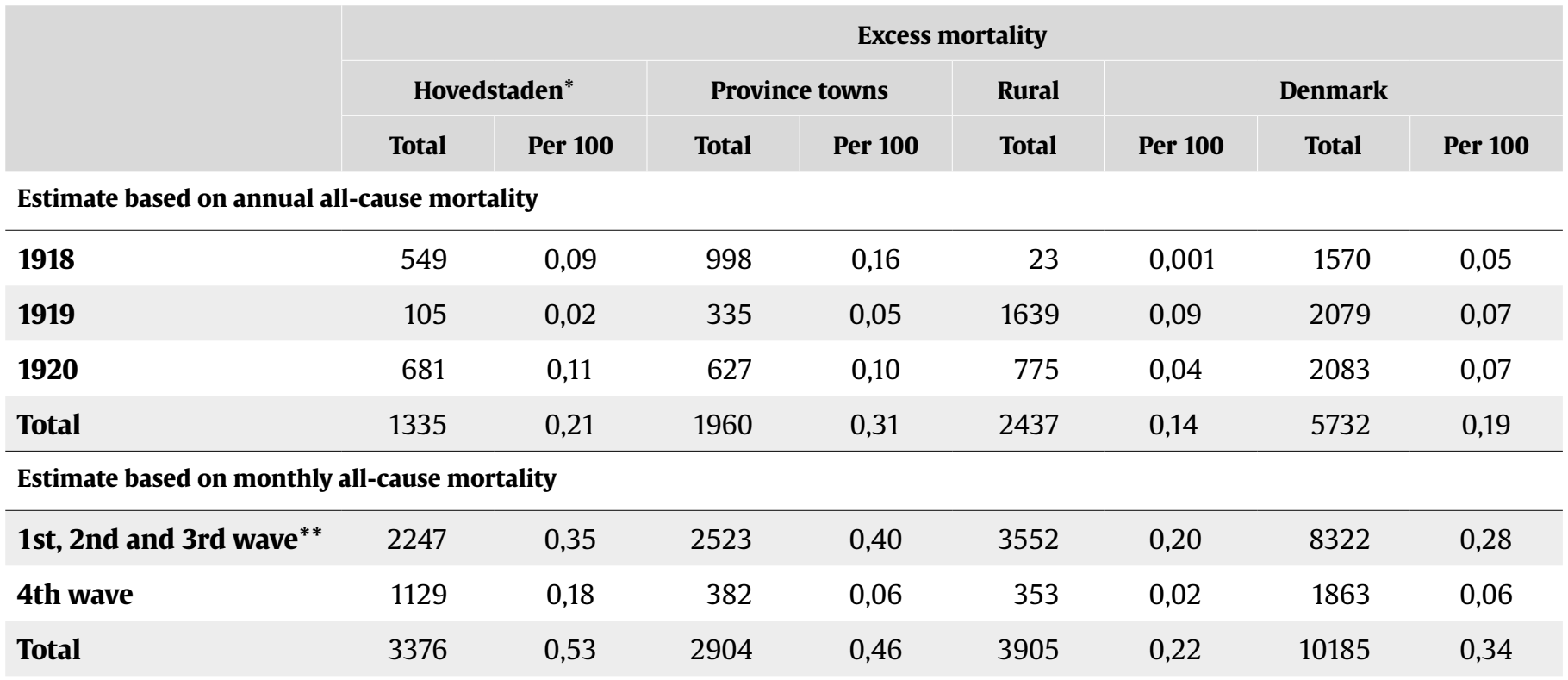

${ }^{*}$ Copenhagen, Frederiksberg and Gentofte

**1st wave: July-September 1918; 2nd wave: October-November 1918; 3rd wave: December-March 1918-1919; 4th wave: January-May 1920.

Source: see Figure 2.

The annual excess mortality showed that there were considerable geographical variations, as was the case with influenza-like morbidity incidence (supplementary Table 1; supplementary Figure 2). ${ }^{5}$ The excess mortality was highest in the Copenhagen area as well as southeastern Zealand and Lolland-Falster. Similarly, overall mortality was lowest in Hjørring, where no measurable excess mortality was recorded in either rural or urban areas.

The overall results of section 2 are that the 1918-20 influenza pandemic did not affect all areas in Denmark equally. Influenza incidence was highest in the urban areas. Geographically, eastern Zealand and Lolland-Falster were hit hardest in terms of mortality, and northwestern Jutland was hit the mildest. Likewise, influenza mortality was largest in the province towns and Copenhagen. We estimated 10.185 excess deaths for the entire pandemic period 1918-1920. Most of these were urban deaths. While our estimates are in line with some previous estimates (Table 1), the low relative excess mortality in rural areas seen in Table 3 combined with the observation that the pandemic was the most severe in the urban areas suggest a disparate impact of the Spanish flu, and that not accounting for these difference may lead to incorrect inferences.

It was not only in Denmark that the influenza pandemic was most severe in urban areas. In Norway, the rural areas also experienced lower mortality than the towns and cities. Geographically, Norway experienced higher mortality along the coasts and in the areas that were connected with the railway (Mamelund, 1998, 92-101). Likewise in Sweden, the mortality burden was lowest among "farmers" and highest among urban "blue-collar workers" (Bengtsson et al., 2018).

\footnotetext{
${ }^{5}$ Monthly mortality data by medical districts exists in unpublished format in the Danish National Archives.
}

As noted earlier, Denmark was the Nordic country hit mildest by the pandemic. Why this is the case is still an open question. Dietary changes with less alcohol- and meat consumption due to rationing could have led to a decrease in mortality. On the other hand, social conditions with unemployment and high food prices may have had a negative impact on people's life courses. It has also been suggested that a multitude of organizations, including a modernized healthcare system, health insurance funds, unions and volunteer organizations secured people from deep poverty and can perhaps partially explain the low mortality (Trier, 2018, 228235).

\section{Causes of mortality variations}

The findings in section 2 show there were substantial inequalities between rural and urban areas in influenza morbidity and mortality in Denmark. As mentioned in the introduction, there are also other regionally determined factors besides urbanization, known to affect influenza mortality. In this section, we study the role of population density, medical care, and socioeconomic factors.

As an indicator for a region's socioeconomic status, we used data on the average income per person. This data was retrieved from Statistics Denmark's series on annual income data. The geographical size of each region was retrieved from the census of 1916 and we used this to compute population density as the number of people per square kilometer. As an indicator for access to medical care, we used figures on the number of doctors by region, retrieved from the Health Board's medical report for 1918. Supplementary Table 2 presents these characteristics for each region. 

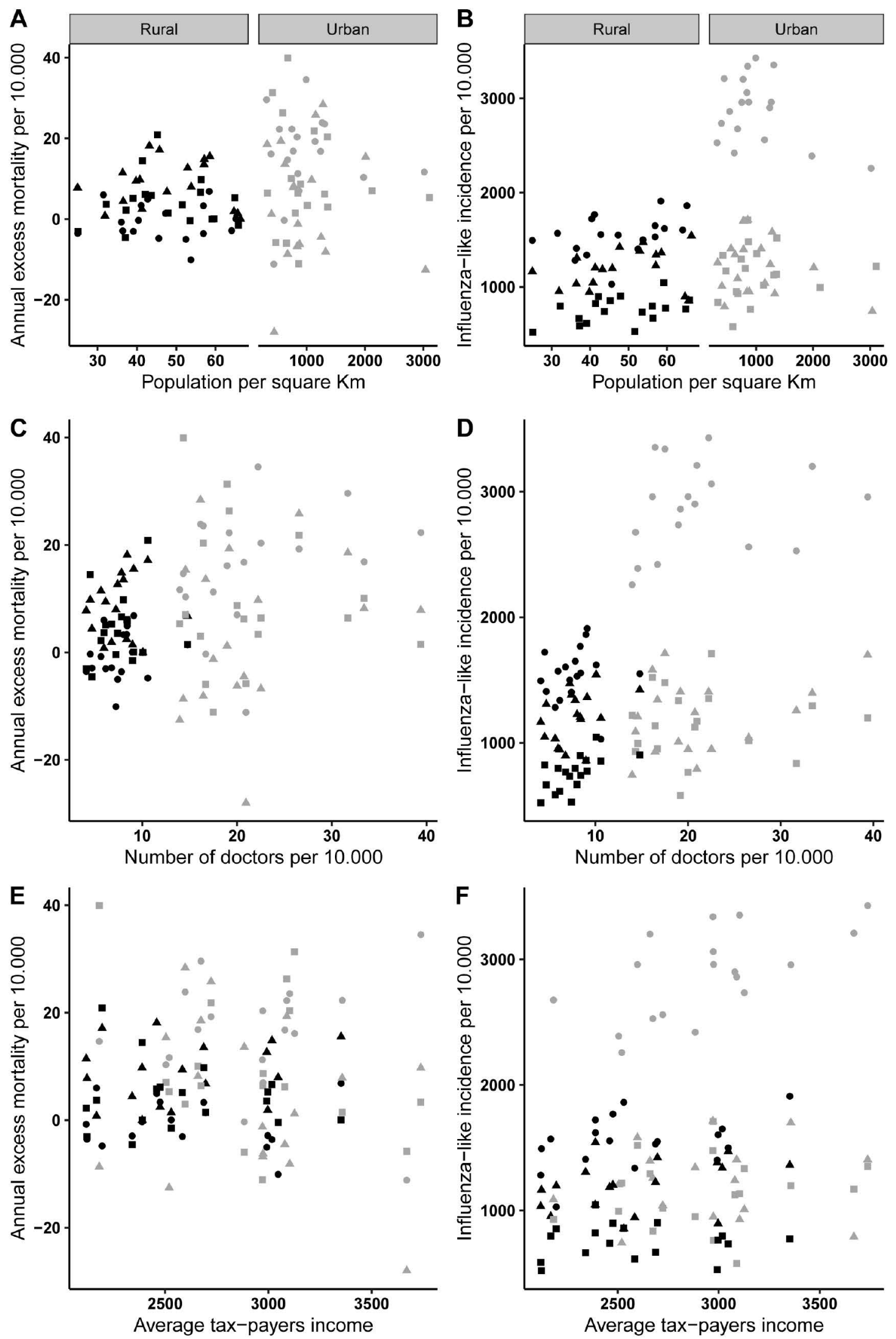

- Rural - Urban

1918 - 1919 - 1920

Figure 3.

Distributions of population characteristics by excess mortality (A, C, E) and influenza-like incidence (B, E, F) in rural and urban areas by year in Denmark 1918-1920. For details by region and sources see supplementary Table 1 and 2 . 
To investigate the association of these factors with excess mortality we used mixed linear regression models accounting for the correlation between urban and rural regions of the same area. As an example, the rural and urban areas of Præstø medical region are likely more similar than the rural and urban areas of Randers medical region (such correlations alone explained around $22 \%$ of the variance in the data). In addition, we also looked at rural and urban areas separately. In our statistical model, we excluded Copenhagen and its surrounding rural areas. Although administratively categorized as rural, they consisted of semi-urban towns with apartments and industry. Excess mortality per 10.000 was used as the dependent variable, and as independent variables we included: influenza like incidence per 10.000 , rural or urban area, average income per person, population per square kilometer, number of doctors per region, and the year $(1918,1919$, or 1920). Each of these variables were investigated univariately and in multivariate models. As mortality is inherently related to incidence and we were mainly interested in differences between urban and rural areas, each multivariate model included at least incidence as well as an indicator for rural or urban areas as predictors. In addition, as both incidence and excess mortality varied from year to year (see Figure 1 and Figure 2), we also included year as a covariate in each model. Figure 3 and 4 explore each of the included variables and supplementary Table 3 presents the univariate and multivariate model results. Interactions between variables were investigated but none were statistically relevant (results not shown). We also checked for multicollinearity, and while some factors were slightly correlated (pearson correlation coefficients up to 0,7 for income and population density), no issues were found in the models with all variance inflation factors well below 10 .
A

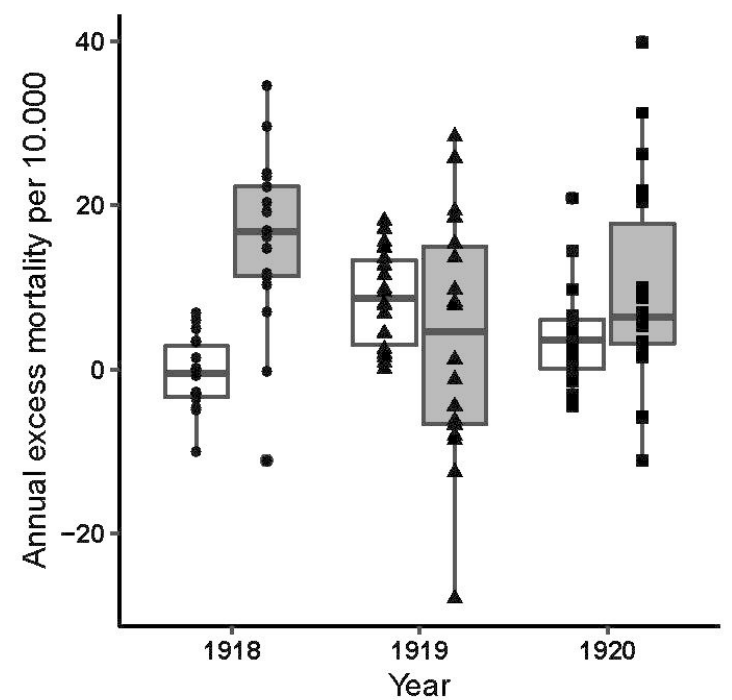

B

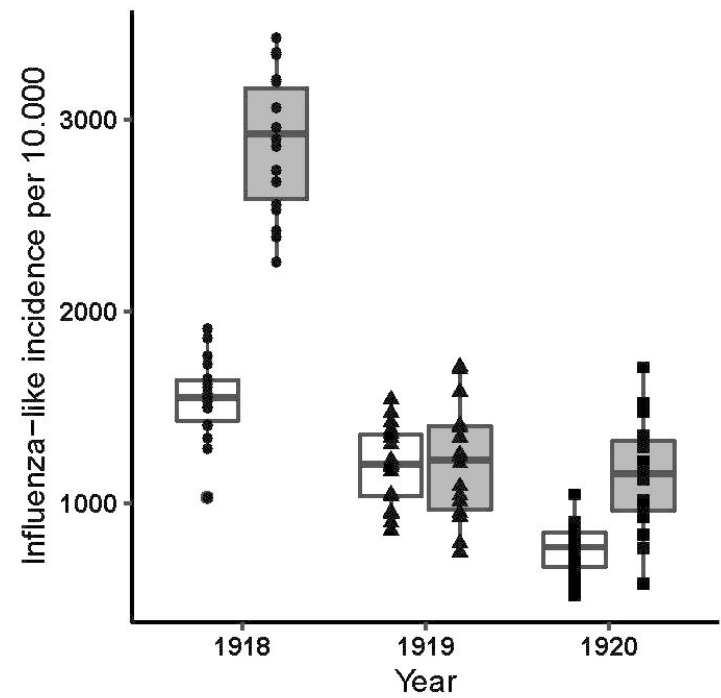

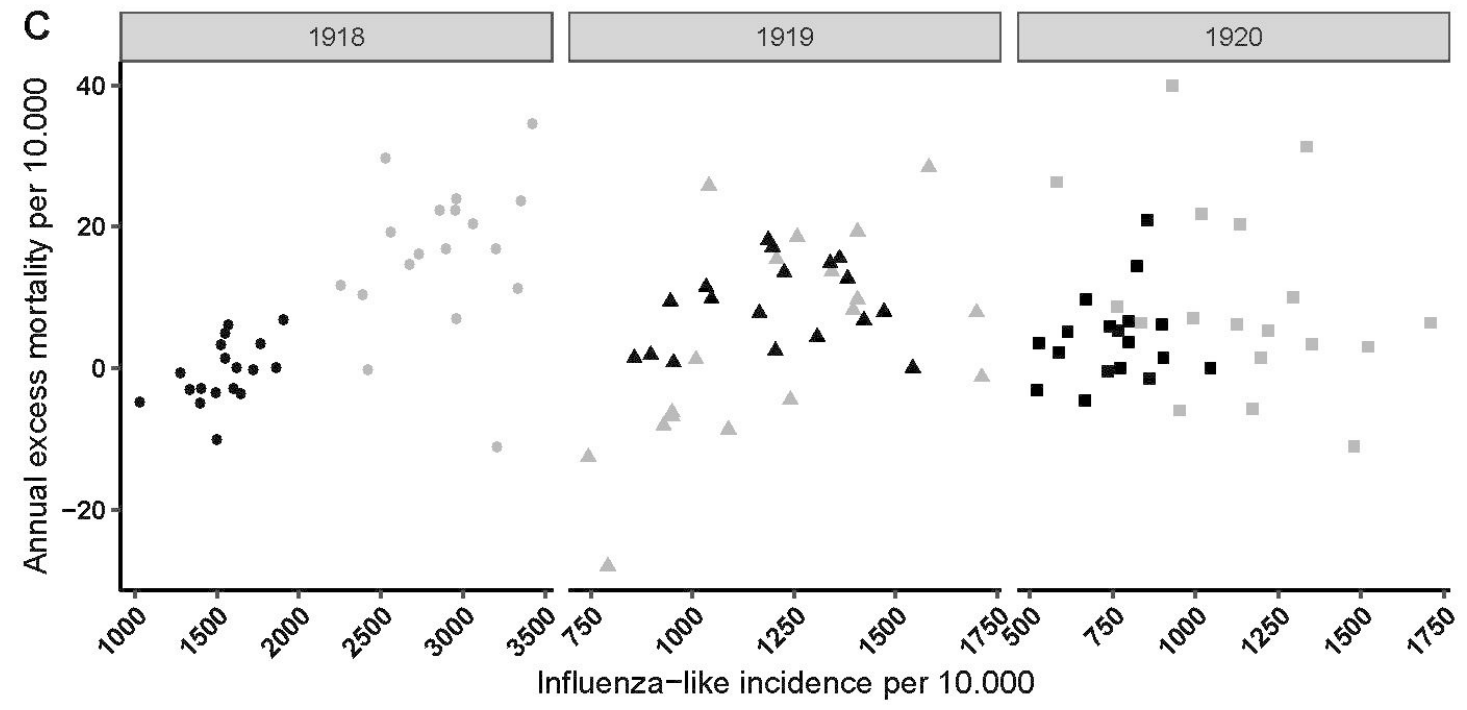

- Rural - Urban 1918 ॥ 1919 - 1920

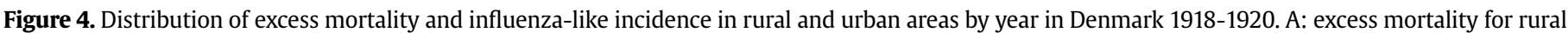

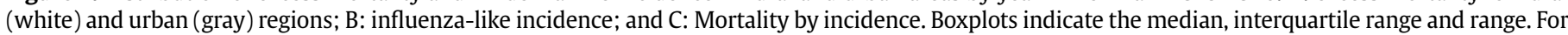
details by region and sources see supplementary Table 1 and 2 . 
In the univariate models, urban regions, influenza-like incidence as well as the number of doctors were statistically associated with an increased excess mortality. When we corrected for urbanization, year, and incidence, a higher average income seemed to reduce the excess mortality. The association with income remained when including also the other covariates ( $p$-value: 0,02 ); the number of doctors in the region ( $p$-value: 0,83 ) and population density ( $p$-value: 0,54$)$ were not associated with excess mortality. It appeared that influenza-like incidence was of main importance, accounting for $48 \%$ of the explained variance in the full model, more so than other factors such as income, which explained $5 \%$. There was also no statistical difference between urban and rural areas when correcting for other factors, meaning the observed differences in urbanization can likely be explained by mostly incidence and to a lesser extent income differences. Below, we discuss the role of population density, medical care and socioeconomic factors in more detail.

\subsection{Population density}

Population density in rural areas differed substantially in the period around 1918; while Zealand historically has always been densely populated, western Jutland had much lower population density (supplementary Table 2 ). As noted above, there was an apparent relationship between influenza morbidity and whether an area was urban or rural. This seems logical, as infectious diseases have more opportunity to spread in more dense populations. A previous study of the 1918 pandemic in Copenhagen determined the effective reproductive number R0 to be around 2 in the 1st wave (Andreasen et al., 2008). The reproduction number is a measure of how infectious a disease is in terms of how many people one infected individual infects on average. As R0 depends on population density, it is likely that the R0 would be lower in rural settings. However, in our statistical analyses we found no associations between excess mortality and population density-neither when restricting to rural or urban regions ( $p$-value rural: 0,22 ; urban: 0,87).

A factor likely to also have affected influenza transmissibility is household size. In the period around 1918, Copenhagen and the province towns were suffering from housing shortage with one-fifth of the urban population living in overpopulated apartments (Hansen and Eriksen, 1984, 78-79). A US study of household infections during the Spanish flu found that once a household member was infected, the risk of infection for others in that household could be up to $32 \%$. Furthermore, the average R0 within infected households was slightly higher at 2.5 (Fraser et al., 2011). Multiple doctors took note of how in the rural areas entire families lay ill, and that there were several members of the same families that died. ${ }^{6}$ According to the 1916 census, there were 339.777 dwellings (houses, farms etc.) in rural Denmark, and the average household size was 5,1 individuals per household including servants. As this is the average regional household size, local variances are not captured. In addition, the type of dwelling and how many families live within each may be of impact on influenza transmission, mortality, and be an all-round indicator for socioeconomic status

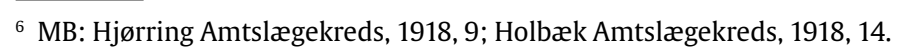

of those that live there, and in extension risk of infectious disease mortality. Micro-level data and analysis would be able to provide an interesting view on the transmission and mortality risks, but are not possible with the data so far available. It would require joining those who died or were recorded with influenza to the population census of 1916, and possibly the census of 1921. A more in-depth analysis of the role of household infection would be able to answer more detailed questions on local transmission events and mortality risks.

\subsection{Medical care}

The period from the 1890's and forth was the "modern breakthrough" of Danish medical sciences. During the 1870's, doctors began to acknowledge the role of antiseptics in treatment, and the discovery of pathogenic bacteria and parasites in the 1880's and 1890's caused fundamental changes in the perception of disease and treatment thereof (Løkke, 1997, 112113; Otto, 2002, 5). At the same time, the number of private general practitioners grew due to economic progress, and older provincial town hospitals were gradually replaced with modern hospitals equipped with isolation wards. With the Health Insurance Law of 1892, all members of acknowledged health insurance funds were eligible for free medical treatment. This meant that people of lower socioeconomic status had better chances of getting medical aid (Løkke, 1997, 106109; Jacobsen and Larsen, 2017, 237-244, 260-61). Progress in the development of biomedical compositions meant that while doctors were unable to treat the influenza infection itself, they were in 1918 treating pneumonia infections that followed with arsenic, quinine and salvarsan (Otto, 2002, 5-7).

This rapid modernization of the healthcare system was however largely an urban phenomenon. As seen in supplementary Table 2, the number of doctors per 10.000 was greater in the urban than rural areas, and rural access to medical care was still far away. In the medical reports of 1918 only little is mentioned about the conditions in the rural areas. When mentions are made of the conditions in the rural areas, it is repeatedly noted that access to medical care was poor. The outbreak of pandemic influenza only increased the need for medical aid. Doctors were forced to improvise in order to facilitate treatment to the rural population, including ad hoc use of whatever vehicle was available to reach their patients. Examples exist of doctors using horses, automobiles, buggies for rough terrain, bicycles, boats and (in the winter) sleds (Trier, 2018, 107-118). Apart from the lack of vehicles and gasoline, doctors frequently faced the challenge of inexperienced medical personnel that did not take the necessary precautions in regards to hygiene and personal protection equipment. One doctor speculates that the lack of proficient care may have cost lives in the rural areas. ${ }^{7}$

Despite the doctors' concerns about the unprepared medical personnel costing lives, we found no statistical association between the number of doctors per 10.000 and the excess mortality in our multivariate models. Similar results were found when we restricted our models to only urban or rural

7 MB: Marselisborg Lægedistrikt, 1918, 22; Hads Lægedistrikt, 1918, 26; Hjørring Amtslægekreds, 1918, 9; Ringkjøbing Amtslægekreds, 1918, 9-10; Hinnerup, 1918, 1; Præstø Amtslægekreds, 1918, 9-10; Københavns Amtslægekreds, 1918, 10-11. 
regions (p-value rural: 0,92: urban: 0,66). This suggests that the availability of medical assistance may not have strongly affected the risk of dying. Proximity to a doctor is however only one indicator for availability of medical care, and we cannot outrule the role of other medical-related factors, such as distance to health care clinics, number of available nurses, number of hospital beds and so forth.

\subsection{The role of socioeconomic conditions}

Studies of the 1918 pandemic in urban areas have reported an association between poverty and influenza mortality (Murray et al., 2006; Mamelund, 2011; Dahl et al., 2020). Other studies have demonstrated how poverty was a risk factor in influenza outcomes. In our analysis, we also found that an average higher income in a region was associated with lower excess mortality ( $p$-value: 0,03 ). When restricting our models to only rural or urban areas, no such associations were found, and if any exists it seemed most prominent in the urban setting (p-value rural 0,52; urban: 0,08 ). This suggests that the average wealth of a region may have been of some importance to pandemic mortality (income explained just $5 \%$ of the variance in the data), but also that this result may not be stable and our dataset may be too limited.

Contrary to other studies such as Mamelund (2006) and Bengtsson et al. (2018), our study cannot compare socioeconomic groups on a local scale, and it is possible that, despite the low overall mortality, micro-level studies of the 1918 pandemic could reveal socioeconomic gradients. Although the mean income was higher in urban areas than in the rural areas, significant variations still existed within both these settings, and associations between mortality and income can thus be exacerbated by gradients of urbanization and socioeconomic status within areas. In Copenhagen and the province towns, an economic and health gap existed between blue-collar and white-collar workers. Inequality between the rural social groups such as tenants and crofters had been decreasing since the 19th century, but differences nevertheless existed. Despite the emergence of share farming in the late 19th century, crofters were often still employed by tenants (Petersen et al., 2011, 36-37). In addition, over 10.000 seasonal workers, mainly from Spain, Poland and Sweden, worked as farmhands on the farms, often living under poor conditions in barns and stables (Hansen and Henriksen, 1984, 70-74). Farmhands may have been particularly vulnerable, as they, contrary to the urban working class, were poorly organized, lived under poor living conditions and had inadequate access to medical care (Trier, 2018, 169-172).

Doctors' reports from the time also indicate that socioeconomic status in rural settings affected one's risk of dying during the 1918 pandemic. Doctors discussed the poor living conditions of the farmhands, noting that their sleeping areas were both very cold and humid. One doctor noted that farm owners did not warm their servants' accommodations because of high fuel prices, and another notes that farmhands with high fever and bloody cough were commonly observed on the farms. ${ }^{8}$ This description illustrates the disparity within local areas,

8 MB: Hjørring Amtslægekreds, 1918, 9; Marselisborg Lægedistrikt, 1918, 22. even to the household level, and signifies that studies of socioeconomic status and pandemic impact requires more detailed information than we were able for this study to provide at this point.

\subsection{Causes of influenza-like incidence variations}

From the above analysis, it was clear that it was, perhaps unsurprisingly, mainly influenza-like incidence that explained the excess mortality. We therefore also investigated the statistical association between the same factors and influenza-like incidence. This was done with similar models as with the excess mortality analysis but using influenza-like incidence as the dependent variable (see supplementary Table 4). Excess mortality was not included as a predictor as incidence necessarily precedes mortality. Here we found that besides the year, the distinction between rural and urban also played a role (p-value: 0,007 ), while income ( $p$-value: 0,10$)$ the number of doctors in the region (p-value: 0,42 ) or population density (p-value: 0,72 ) were not associated with increased incidence. This corroborates our idea that the driver of differences in excess mortality between rural and urban areas are differences in influenza-like incidence. Our analysis could however not pinpoint the cause of these differences.

\section{Discussion}

\subsection{Other contributing factors}

In this analysis, the role of population density, access to medical care and socioeconomic differences are discussed. Of these, we found that the main driver of influenza mortality was, not surprisingly, influenza incidence and that income also played a role. The distinction between rural and urban areas does not seem to be an independent factor associated with excess mortality. The mortality differences we observe between rural and urban regions may be driven by differences in influenza incidence that could arise through more local socioeconomic or demographic differences. It is also likely that age may explain some of the differences. The Spanish flu was characterized as being most severe among younger individuals from 15-40 years old (Olson et al., 2005; Andreasen et al., 2008; van Wijhe et al., 2018). Due to the growing urbanization in the period around the Spanish flu, especially Copenhagen and to some degree the province towns saw a demographic shift with an increasingly younger population. The combination of a higher population density and a younger population could explain in part the higher urban mortality. Supplementary Figure 3 illustrates the age distributions in Copenhagen, the province towns and rural regions in 1911 and 1921. Interestingly, the rural areas had a higher proportion of individuals under age 20, while Copenhagen and the province towns had a higher proportion for ages over 20 in both census, and it is likely that this would also be the case during the pandemic years. Since the pandemic mainly caused increased mortality between 20 and 40 years of age, this demographic difference may explain partly the lower excess mortality in the rural areas. We however also note that the difference between the province towns and rural areas is not large, and as Copenhagen was excluded from the statistical analyses, the impact of age differences may be limited but residual confounding by age 
likely remains. We could not correct for these demographic differences as no age-structured data was available at the regional level.

The effect of mitigation strategies on influenza morbidity and mortality during the 1918-20 Spanish flu is documented in several studies. US cities that applied the strictest measures to slow down the spread were also the ones with the lowest mortality (Markel et al., 2007). Evidence from Denmark furthermore suggests that closing schools, theatres and cinemas did indeed reduce the impact of the pandemic in the province towns (Dahl et al., 2020). In the rural areas, the decision to close schools was made by the individual parishes' parish commissions. While records for dates of school closings in the province towns can be obtained through newspaper articles and questionnaires from the Health Board to the doctors, no known records are kept of the dates of school closings in rural parishes, precluding a detailed analysis at this time of the impact of such mitigation strategies. ${ }^{9}$

In a questionnaire about the pandemic from the Health Board to all doctors in Denmark in 1919, they were asked about the role of mitigation strategies implemented in their districts. While little is mentioned about school closings in rural settings, what is mentioned is that schools often closed soon after the first pandemic cases occurred in the parish. In one rural district, 4 parishes out of 40 parishes did not close schools at any time during the pandemic. In regard to restrictions on dances, very little is mentioned as well. One doctor mentions encouraging the rural population in his district to cancel dances and parties, and experiencing that people did not follow his advice. ${ }^{10}$ In a journal article, a doctor from Lolland describes an outbreak at a wedding anniversary in a village in November. A child recovering from influenza attended the anniversary and 10 people were subsequently infected (Hansen, 1919, 560-561). While illustrative, these examples do not mean that everyone in the rural settings disobeyed the medical authorities' advice. Together with the overall lack of reports on the Spanish flu in the rural areas by doctors, they can however indicate a disconnect between the rural population and the health authorities. As there are indications that the pandemic came to rural areas slightly after urban areas, they may have had some forewarning and thus time to prepare (Figure 1).

Furthermore, the role of nutrition is considered pivotal in terms of overall health and mortality risk. Studies of childhood mortality in Denmark show regional variations with some areas being characterized as "high mortality areas" and other areas characterized as "low mortality areas". While the differences in childhood mortality decreased throughout the 19th century, regional variations nevertheless still existed in the period 1916-20 (Løkke, 1998, 125-183). Height is often used as

\footnotetext{
${ }_{9}$ Obtaining dates for school closings in the Danish province towns from newspaper bulletins were done by Dahl et al. 2020 .

${ }^{10}$ Sporadic school openings in the districts' rural parishes is mentioned in the questionnaires from the district doctors from Herlufsholm, Københavns søndre, Middelfart, Nordfyn, Næstved, Samsø, Thy, Varde, Rougsø, Lemvig, Kalundborg, and Faaborg. In Rougsø district, the district doctor added notes on school closings from all parishes. The note on the rural population not following advice comes from the district doctor for Frederikshavn district in his questionnaire reply. Source: Danish National Archives, Sundhedsstyrelsens arkiv, Oplysninger om influenzaen i Danmark 1918-1919.
}

an indicator for the overall health state of a given population, where a higher average height is considered indicative of an overall better health. A study of 22 year-old Danish military recruits' body height from 1903-1904 demonstrated a 2,3 cm difference in the average height between the counties with the highest and lowest mean body height, indicating significant regional variances in overall health even in the 20th century (Mackeprang, 1907-11, 13-68).

Another factor that may have contributed to the spread of influenza is the Danish military. Epidemics are known to have occurred in the 19th century following the presence of military troops (Løkke, 1998, 175-176). Despite Denmark's neutral role in World War I, the Danish military was mobilized, and 35.000 young adults were gathered closely together in garrisons under generally unsanitary conditions at the time of the pandemic. The soldiers were not stationed at one garrison throughout the entire pandemic and travelled around the country by train, residing in leased hotels and barracks in different towns. While stationed, soldiers interacted with the local population during social events. It is likely that through these interactions, influenza was first introduced into the garrisons. When the first wave of the pandemic broke out, it immediately caused a major outbreak in the military garrisons. Outbreaks among soldiers continued into the fall, where they became more malignant (Trier, 2018, 53-84). Taking the interaction between soldiers and civilians into account, it is likely that outbreaks among stationed soldiers could have diffused into the civilian population of towns or nearby rural villages and possibly from region to region.

\subsection{Limitations of the study}

In this study, we used annual mortality data for the larger medical regions. Estimates of excess mortality based on annual and monthly morbidity and mortality data may hide interesting patterns otherwise observed from more detailed weekly data and lead to underestimation of pneumonia and influenza incidence attributable to pandemic deaths. Unfortunately, such data is only available for Copenhagen (Andreasen et al., 2008). In addition to the lack of temporal resolution, our study is also limited by the lack of local variation in other variables. As such, we were unable to capture the role of varying household sizes, nor could we adequately capture local socioeconomic differences. For such analysis, individual, household, or bare minimum township level information is required. Unfortunately, such information was not available at the time of writing, but efforts are being made to collect such information. Similarly, our data lacked the detail to study the role of age-patterns. As mentioned already, the pandemic was most severe among young adults, and this demographic group constituted a larger part of the province towns than the rural areas. Accounting for age allows the study of these well-known age patterns in more local settings.

The statistical models we employed thus do not convey an accurate picture of the socioeconomic status associations, population density, or medical care, but may provide a starting point for further study as more detailed data becomes available. Finally, the lack of detailed information on school closings and openings in the rural areas means that we were unable to study the effect of mitigation strategies between rural and urban regions quantitatively. 


\section{Conclusion}

The 1918-20 influenza pandemic was primarily an urban disease. Both incidence and excess mortality associated with pandemic influenza was highest in the Copenhagen and the province towns. We found that the main driver affecting influenza-related mortality seems to have been influenza incidence, and other factors such as population density and availability of medical care did not seem to play major roles on a regional basis. Socioeconomic differences may however have played a role, in particular in the urban areas and likely on a local scale, as was also suggested by doctors at the time and later research. Despite the rural populations having less access to medical advice and care, it nevertheless was not associated with an increase in mortality. Our analysis reflected more general patterns of lower relative mortality in rural than in urban areas, although large variations were observed. While our study cannot explain variances in mortality or incidence on the regional scale, the differences between urban and rural patterns could possibly be explained by more local demographic and socioeconomic variations-likely resulting from urbanization-which lead to more exposure to the pandemic virus. That influenza mortality was highest in the urban areas also indicates that this distinction is of importance for excess mortality estimates, in particular, when estimates may be heavily biased when such calculations are mainly based on data from cities; the mortality in Copenhagen was for example large compared to the rural areas. Among the rural areas, there were considerable differences with areas in Zealand being affected more than the rural areas of northern Jutland. Especially the rural areas closest to the larger cities Copenhagen, Århus, and Odense were affected more.

\section{Acknowledgements}

We would like to thank Hans Trier and Tommy Heisz for sharing historical source material in a time when archives and libraries are closed due to the COVID-19 pandemic. We would also like to thank professor Signild Vallgårda, University of Copenhagen for comments, and Raimundo José Elicer for help with translations. This work was supported by a grant from the Independent Research Fund Denmark (grant \# 8020-00284), as well as the Carlsberg Foundation, Semper Ardens Research Project (grant \# CF20-0046).

\section{Sources}

Danish National Archives, Sundhedsstyrelsens arkiv, Medicinalberetninger. Jylland. 1918-1919.

Danish National Archives, Sundhedsstyrelsens arkiv, Medicinalberetninger. Øerne. 1918-1919.

Danish National Archives, Sundhedsstyrelsens arkiv, Medicinalberetninger. Fyn. 1919.

Danish National Archives, Sundhedsstyrelsens arkiv, Oplysninger om influenzaen i Danmark 1918-1919.

Hansen, H.J., 1918-1923. Medicinalberetning for den Danske Stat. H. Hagerups Forlag, Copenhagen.

Statistics Denmark, Statistiske Meddelelser Rk. 4. Bind 56 ; Hæfte 1. Ansættelserne til Indkomst- og Formueskatten for Skatteaaret 1917/1918.
Statistics Denmark, Statistisk Tabelværk, 5. Række, Litra A, 5 , 1905. Befolkningsforholdene i Danmark i det 19. Aarhundrede. Statistics Denmark, Statistisk Tabelværk, Rk.4. Litra A ; Nr. 8, b. Census of 1890.

Statistics Denmark, Statistisk Tabelværk, Rk. 5. Litra A ; Nr. 3. Census of 1901 part 1.

Statistics Denmark, Statistisk Tabelværk, Rk. 5. Litra A ; Nr. 9. Census of 1911 part 1.

Statistics Denmark, Statistisk Tabelværk, Rk. 5. Litra A ; Nr. 14. Census of 1916.

Statistics Denmark, Statistisk Tabelværk, Rk. 5. Litra A ; Nr. 16. Census of 1921.

Statistics Denmark, Statistisk Tabelværk, Rk. 5. Litra A ; Nr. 13. Ægteskaber, Fødte og Døde i Aarene 1911-15.

Statistics Denmark, Statistisk Tabelværk, Rk. 5. Litra A ; Nr. 15. Ægteskaber, Fødte og Døde i Aarene 1916-20.

Statistics Denmark, Statistisk Tabelværk, Rk. 5. Litra A ; Nr. 17. Ægteskaber, Fødte og Døde i Aarene 1921-25.

\section{Bibliography}

Andreasen, V., Viboud, C. and Simonsen, L., 2008. Epidemiologic Characterization of the 1918 Influenza Pandemic Summer Wave in Copenhagen: Implications for Pandemic Control Strategies, 2008. Journal of Infectious Diseases, 197 270-278.

Andreasen, V. and Simonsen, L., 2011. The perils of using annual all-cause mortality data to estimate pandemic influenza burden. Vaccine, 29S, B49-55.

Bengtsson, T., Dribe, M. and Eriksson, B., 2018. Social class and excess mortality in Sweden during the 1918 influenza pandemic. American Journal of Epidemiology, 187 (12), 2568-2576.

Clay, K., Lewis, J. and Severnini, E. R., 2019. What Explains Cross-Country Variation in Mortality During the 1918 Influenza Pandemic? Evidence from 438 U.S. Cities. Economics \& Human Biology, 35, 42-50.

Correia, S., Luck, S. and Verner, E., 2020. Pandemics Depress the Economy, Public Health Intervetions Do Not: Evidence from the 1918 Flu. SSRN.

Dahl C.M., Worm Hansen, C. and Sandholt Jensen, P., 2020. The 1918 Epidemic and a V-shaped Recession: Evidence from Municipal Income Data. Covid Economics, 6, 137-162.

Fraser, C., Cummings, D.A.T., Klinkenberg, D., Burke, D.S. and Ferguson, N.M., 2011. Influenza Transmission in Households during the 1918 Pandemic. American Journal of Epidemiology, 174 (5), 505-514.

Hansen, C. A., 1919. Iagttagelser fra Influenzapandemien 1918. Ugeskrift for Læger, 81 (13), 551-561.

Hansen, S.Å. and Henriksen, I., 1984. Dansk socialhistorie 1914-1939. Gyldendalske Boghandel, Copenhagen.

Hatchett, R. J., Mercher, C.E. and Lipsitch, M., 2007. Public health interventions and epidemic intensity during the 1918 influenza pandemic. PNAS, 104 (18) 7582-7587.

Jacobsen, K. and Larsen, K., 2017. Ve og Velfærd. Læger, sundhed og samfund gennem 200 år. FADL's Forlag, Copenhagen.

Kolte, I. V., Skinhøj, P., Keiding, N. and Lynge, E., 2008. The Spanish flu in Denmark Scandinavian Journal of Infectious Diseases, 40, 538-546.

Løkke, A., 1997. The "Antiseptic" Transformation of Danish Midwives, 1860-1920. In: Marland, H. and Rafferty, A. M.(eds.). Midwives, Society and Childbirth: Debates and Controversies in the Modern Period. Routledge, London, pp. 102-133.

Løkke, A., 1998. Døden i barndommen. Spædbørnsdødelighed og moderniseringsprocesser i Danmark 1800 til 1920. Gyldendalske Boghandel, Copenhagen.

Mackeprang, E. (1907). De Værnepligtiges Legemshøjde i Danmark. Meddelelser om Danmarks Antropologi, 1, 1907-1911: 13-68.

Mamelund, S., 1998. Spanskesyken i Norge 1918-1920. Diffusjon og demografiske konsekvenser. Universitetet i Oslo.

Mamelund, S., 2006. A socially neutral disease? Individual social class, household wealth and mortality from Spanish influenza in two socially contrasting parishes in Kristiania 1918-19. Social Science \& Medicine, 62, 923-940.

Mamelund, S., 2011. Geography may explain adult mortality from the 1918-20 influenza pandemic. Epidemics, 3, 46-60. 
Markel, H., Lipman, H. B., Navarro, J. A., Sloan, A., Michalsen, J. R., Stern, A. M. and Cetron, M.S., 2007. Nonpharmaceutical interventions implemented by US cities during the 1918-1919 influenza pandemic. JAMA, 298 (6), 644-655.

Murray, C. L., Lopez, A. D, Chin, B., Feehan, D., and Hill, K. H., 2006. Estimation of potential global pandemic influenza mortality on the basis of vital registry data from the 1918-1920 pandemica quantitative analysis. The Lancet, 368, 2211-2218.

Olson, D. R., Simonsen, L., Edelson, P. J., and Morse, S. S., 2005. Epidemiological evidence of an early wave of the 1918 influenza pandemic in New York City. PNAS, 102 (31), 11059-11063.

Otto, L., 2002. Sygdommen kom som en Explosion. Den spanske syge i Danmark. Fortid og nutid, 3-25.

Patterson, K. D. and Pyle, G. F., 1991. The Geography and Mortality of the 1918 Influenza Pandemic. Bulletin of the History of Medicine, 65 (1), 4-21.

Petersen, J. H., Petersen, K. y Christiansen, N. F., 2011. Dansk velfærdshistorie, bind 2 1898-1933. Syddansk Universitetsforlag, Odense.
Sattenspiel, L., 2011. Regional patterns of mortality during the 1918 influenza pandemic in Newfoundland. Vaccine, 29: B33-37.

Simonsen, L., Chowell, G., Andreasen, V., Gaffey, R., Barry, J., Olson, D.and Viboud, C., 2018. A Review of the 1918 Herald Pandemic Wave: Importance for Contemporary Pandemic Response Strategies. Annals of Epidemiology, 28 (5): 281-288.

Sood, L. and Sood, V., 2020. Being African American and Rural: A Double Jeopardy from Covid-19. The Journal of Rural Health.

Trier, H., 2018. Angst og Engle. Den spanske syge i Danmark. Gads forlag, Copenhagen.

Van Wijhe, M., Ingholt, M. M., Andreasen, V., and Simonsen, L., 2018. Loose ends in the epidemiology of the 1918 pandemic: explaining the extreme mortality risk in young adults. American Journal of Epidemiology, 187 (12): 25032510 .

Zahnd, W., 2020. The COVID-19 Pandemic Illuminates Persistent and Emerging Disparities among Rural Black Populations. The Journal of Rural Health.

\section{Supplements}

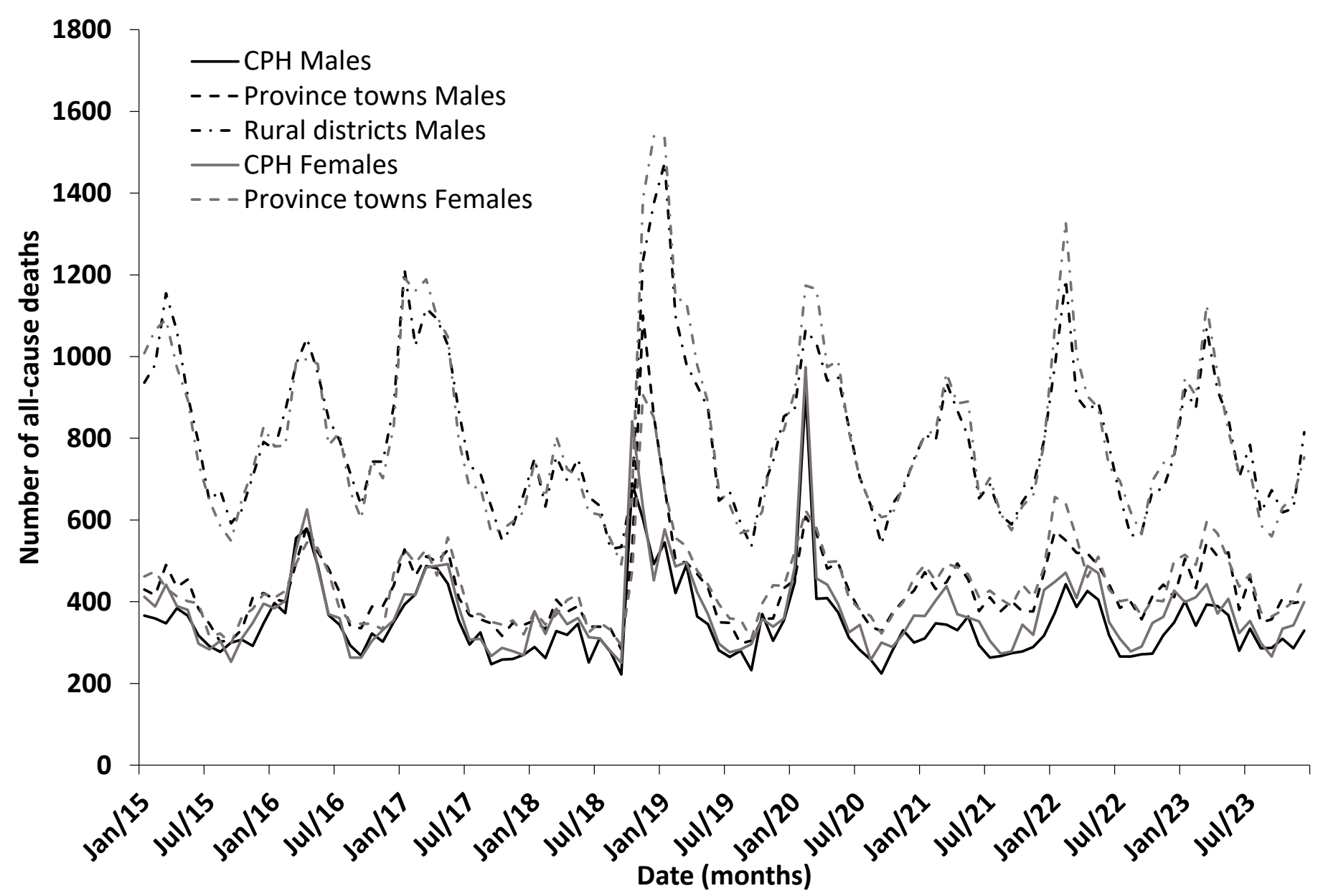

Supplementary Figure 1. Monthly all-cause deaths by sex for the period 1915-1923 in Copenhagen (CPH), province towns, and rural areas in Denmark. Male deaths are represented by solid lines and female deaths by interrupted lines.

Source: Statistics Denmark: “Ægteskaber, Fødte og Døde” volumes 1911-1915, 1916-1920 and 1921-1925 and Medicinalberetning for den danske stat 1918. 


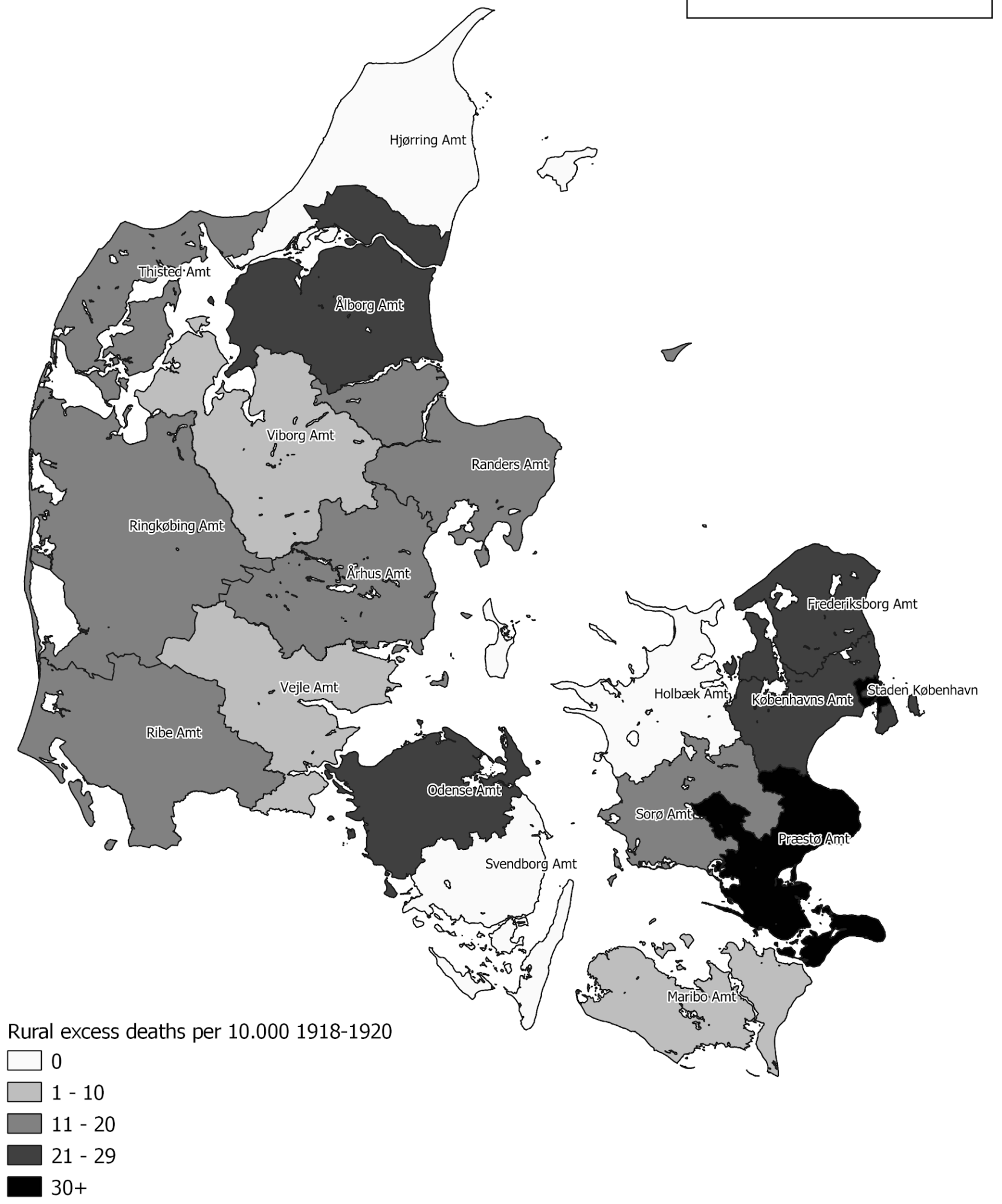




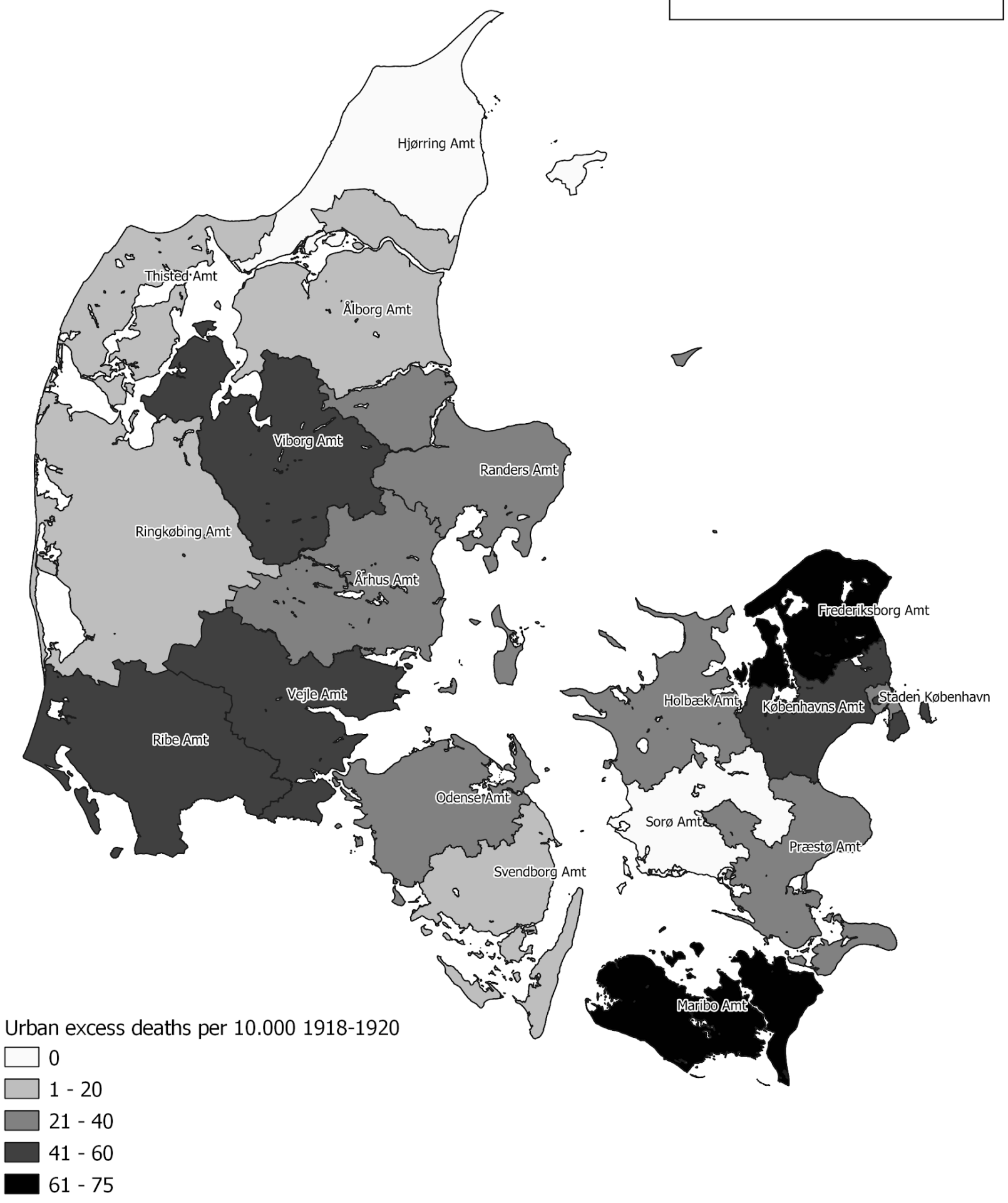

Supplementary Figure 2. Rural and urban excess deaths per 10.000 by region combined for 1918-1920. Source: Statistics Denmark: “Ægteskaber, Fødte og Døde” volumes 1911-1915, 1916-1920 and 1921-1925 
A
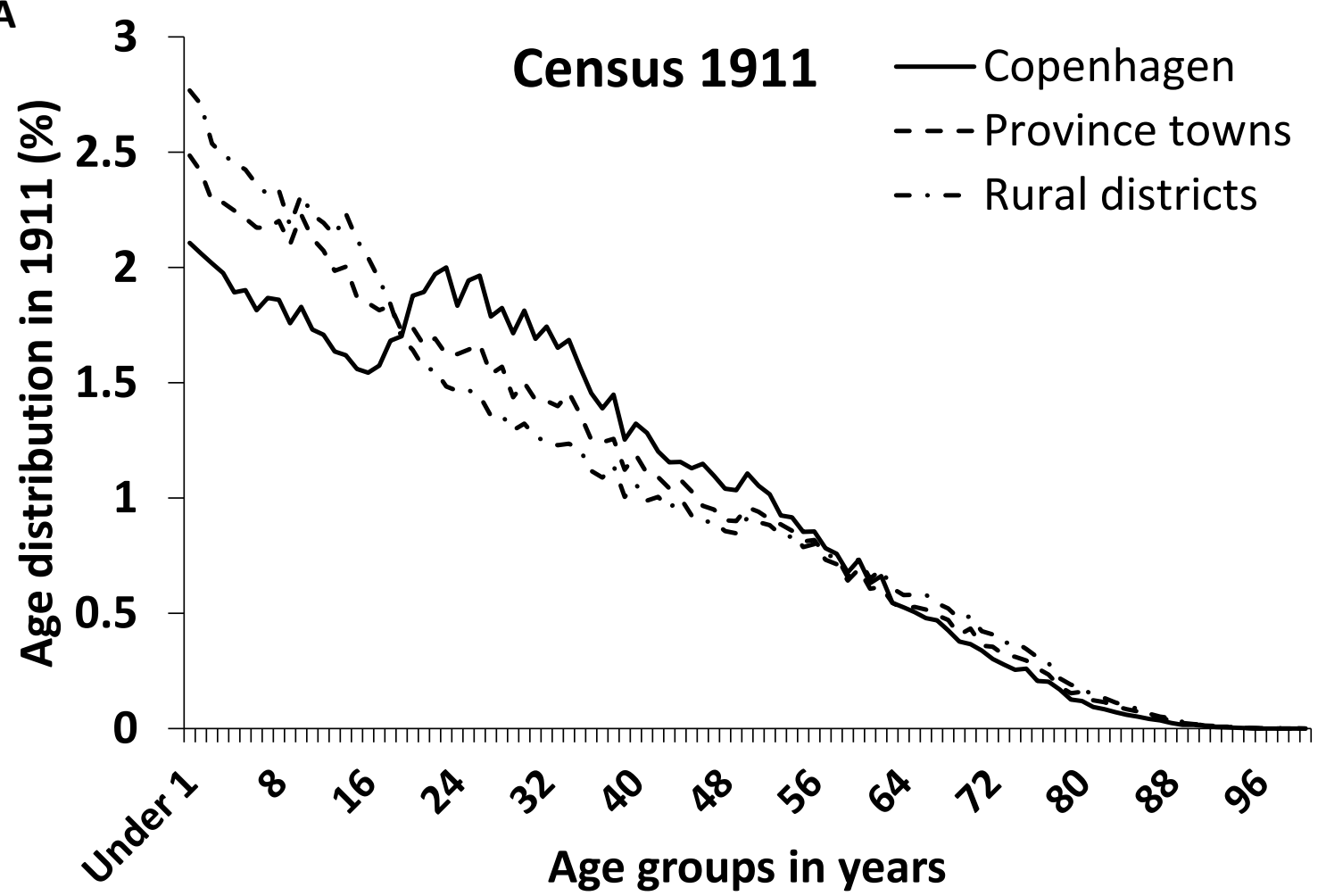

B

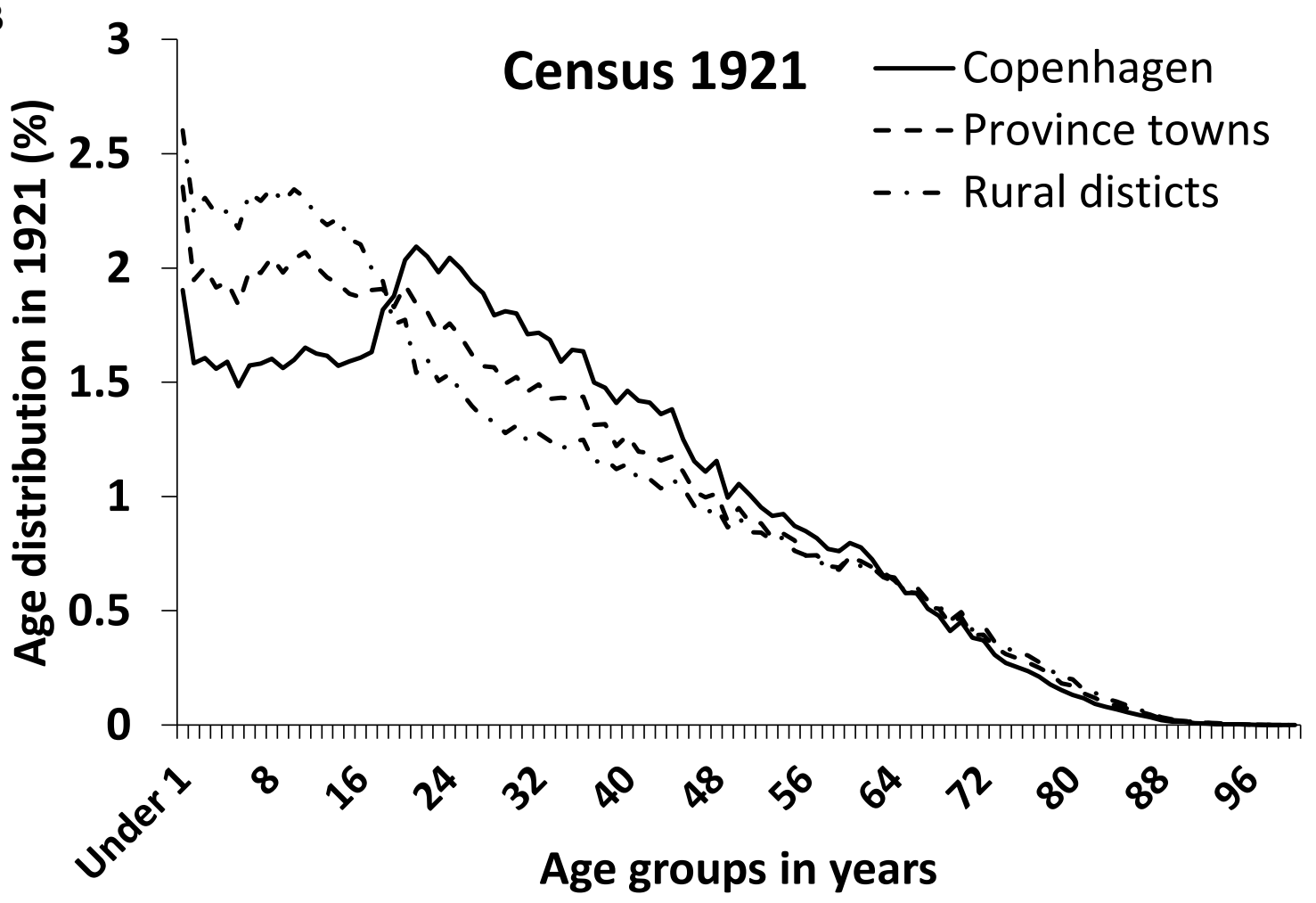

Supplementary Figure 3. Age distribution in Copenhagen, Province towns and Rural districts according to the 1911 and 1921 census. Source: Statistics Denmark: census of 1911 and census of 1921. 


\section{Supplementary Table 1}

Incidence and excess mortality in rural and urban areas in Denmark 1918-1920, based on annual mortality

\begin{tabular}{|c|c|c|c|c|c|c|c|}
\hline \multirow[b]{2}{*}{ Region } & \multirow[b]{2}{*}{ Type of region } & \multicolumn{3}{|c|}{ Pneumonia and influenza incidence per 10.000} & \multicolumn{3}{|c|}{ Excess all-cause mortality per 10.000} \\
\hline & & 1918 & 1919 & 1920 & 1918 & 1919 & 1920 \\
\hline \multirow{2}{*}{ Hovedstaden } & Urban & 1996,3 & 811,1 & 914,5 & 8,6 & 1,6 & 10,2 \\
\hline & Rural & 2380,2 & 1177,8 & 1179,5 & 8,9 & 22,9 & 14,5 \\
\hline \multirow{2}{*}{ Roskilde Amtslægekreds } & Urban & 3428,3 & 1406,1 & 1352,0 & 34,5 & 9,7 & 3,4 \\
\hline & Rural & 1619,9 & 1542,3 & 1044,7 & & & \\
\hline \multirow{2}{*}{ Frederiksborg Amtslægekreds } & Urban & 2559,6 & 1040,1 & 1017,8 & 19,3 & 25,8 & 21,8 \\
\hline & Rural & 1910,4 & 1361,9 & 773,9 & 6,9 & 15,5 & 0,1 \\
\hline \multirow{2}{*}{ Holbæk Amtslægekreds } & Urban & 2957,6 & 1699,8 & 1198,1 & 22,3 & 7,9 & 1,5 \\
\hline & Rural & 1530,5 & 1225,6 & 667,7 & 3,3 & 13,5 & 9,8 \\
\hline \multirow{2}{*}{ Sorø Amtslægekreds } & Urban & 3339,7 & 1712,3 & 1478,6 & 11,2 & $-1,2$ & $-11,1$ \\
\hline & Rural & 1499,9 & 1471,6 & 733,9 & $-10,1$ & 8,0 & $-0,4$ \\
\hline \multirow{2}{*}{ Præstø Amtslægekreds } & Urban & 3201,8 & 1395,5 & 1293,9 & 16,9 & 8,2 & 10,1 \\
\hline & Rural & 1649,8 & 1339,0 & 796,5 & $-3,6$ & 14,8 & 6,6 \\
\hline \multirow{2}{*}{ Bornholm Amtslægekreds } & Urban & 2676,4 & 1088,1 & 929,8 & 14,7 & $-8,7$ & 39,9 \\
\hline & Rural & 1029,0 & 1196,9 & 854,2 & $-4,8$ & 17,1 & 20,9 \\
\hline \multirow{2}{*}{ Lolland-Falster Amtslægekreds } & Urban & 2860,9 & 1406,3 & 579,6 & 22,3 & 19,3 & 26,3 \\
\hline & Rural & 1402,2 & 1381,6 & 528,1 & $-5,0$ & 12,7 & 3,6 \\
\hline \multirow{2}{*}{ Svendborg Amtslægekreds } & Urban & 2901,0 & 1240,8 & 1125,3 & 16,8 & $-4,5$ & 6,2 \\
\hline & Rural & 1603,7 & 896,8 & 765,7 & $-2,9$ & 1,9 & 5,3 \\
\hline \multirow{2}{*}{ Odense Amt } & Urban & 3353,4 & 928,4 & 1134,8 & 23,6 & $-8,1$ & 20,4 \\
\hline & Rural & 1862,5 & 856,4 & 859,9 & 0,0 & 1,4 & $-1,5$ \\
\hline \multirow{2}{*}{ Odense Amtslægekreds } & Urban & 3296,6 & 829,7 & 1164,2 & & & \\
\hline & Rural & 1941,7 & 872,3 & 865,1 & & & \\
\hline \multirow{2}{*}{ Assens Amtslægekreds } & Urban & 3630,7 & 1419,6 & 994,7 & & & \\
\hline & Rural & 1721,7 & 827,9 & 850,4 & & & \\
\hline \multirow{2}{*}{ Vejle Amtslægekreds } & Urban & 2959,7 & 1581,9 & 1519,7 & 23,9 & 28,4 & 3,0 \\
\hline & Rural & 1555,8 & 1186,4 & 739,9 & 4,9 & 18,1 & 5,8 \\
\hline \multirow{2}{*}{ Århus Amt } & Urban & 2388,8 & 1207,0 & 993,9 & 10,3 & 15,4 & 7,0 \\
\hline & Rural & 1550,0 & 1422,1 & 903,1 & 1,4 & 6,8 & 1,5 \\
\hline \multirow{2}{*}{ Skanderborg Amtslægekreds } & Urban & 2857,3 & 1013,9 & 1015,4 & & & \\
\hline & Rural & 1505,8 & 1308,5 & 878,1 & & & \\
\hline \multirow{2}{*}{ Århus Amtslægekreds } & Urban & 2116,7 & 1318,9 & 981,7 & & & \\
\hline & Rural & 1600,0 & 1551,6 & 931,6 & & & \\
\hline \multirow{2}{*}{ Randers Amtslægekreds } & Urban & 3062,1 & 949,4 & 1709,2 & 20,4 & $-6,8$ & 6,4 \\
\hline & Rural & 1767,9 & 1204,0 & 898,8 & 3,4 & 2,5 & 6,1 \\
\hline & Urban & 2258,2 & 743,0 & 1218,4 & 11,7 & $-12,6$ & 5,3 \\
\hline Alborg Amtslægekreds & Rural & 1338,3 & 945,3 & 613,9 & $-3,0$ & 9,4 & 5,1 \\
\hline & Urban & 3209,0 & 791,1 & 1170,9 & $-11,2$ & $-28,0$ & $-5,8$ \\
\hline Hjørring Amtslægekreds & Rural & 1722,0 & 1046,1 & 823,2 & $-0,3$ & 9,8 & 14,5 \\
\hline & Urban & 2960,7 & 949,3 & 763,9 & 7,0 & $-6,2$ & 8,7 \\
\hline Thisted Amtslægekreds & Rural & 1408,8 & 1306,9 & 664,9 & $-2,9$ & 4,4 & $-4,6$ \\
\hline & Urban & 2528,3 & 1257,6 & 835,6 & 29,6 & 18,5 & 6,4 \\
\hline Viborg Amtslægekreds & Rural & 1281,9 & 1033,0 & 587,2 & $-0,8$ & 11,5 & 2,2 \\
\hline & Urban & 2420,2 & 1343,0 & 951,5 & $-0,3$ & 13,6 & $-6,0$ \\
\hline Ringkøbing Amtslægekreds & Rural & 1493,4 & 1164,3 & 521,3 & $-3,5$ & 7,8 & $-3,1$ \\
\hline & Urban & 2735,4 & 1008,3 & 1334,9 & 16,1 & 1,2 & 31,3 \\
\hline Ribe Amtsiægekreds & Rural & 1569,8 & 953,0 & 796,9 & 6,0 & 0,8 & 3,7 \\
\hline
\end{tabular}

Source: Medicinalberetning for den danske stat 1918-1920; Statistics Denmark: “Ægteskaber, Fødte og Døde”, volumes 1911-1915, 1916-1920 and 1921 -1925. 


\section{Supplementary Table 2}

Characteristics of rural and urban regions in Denmark

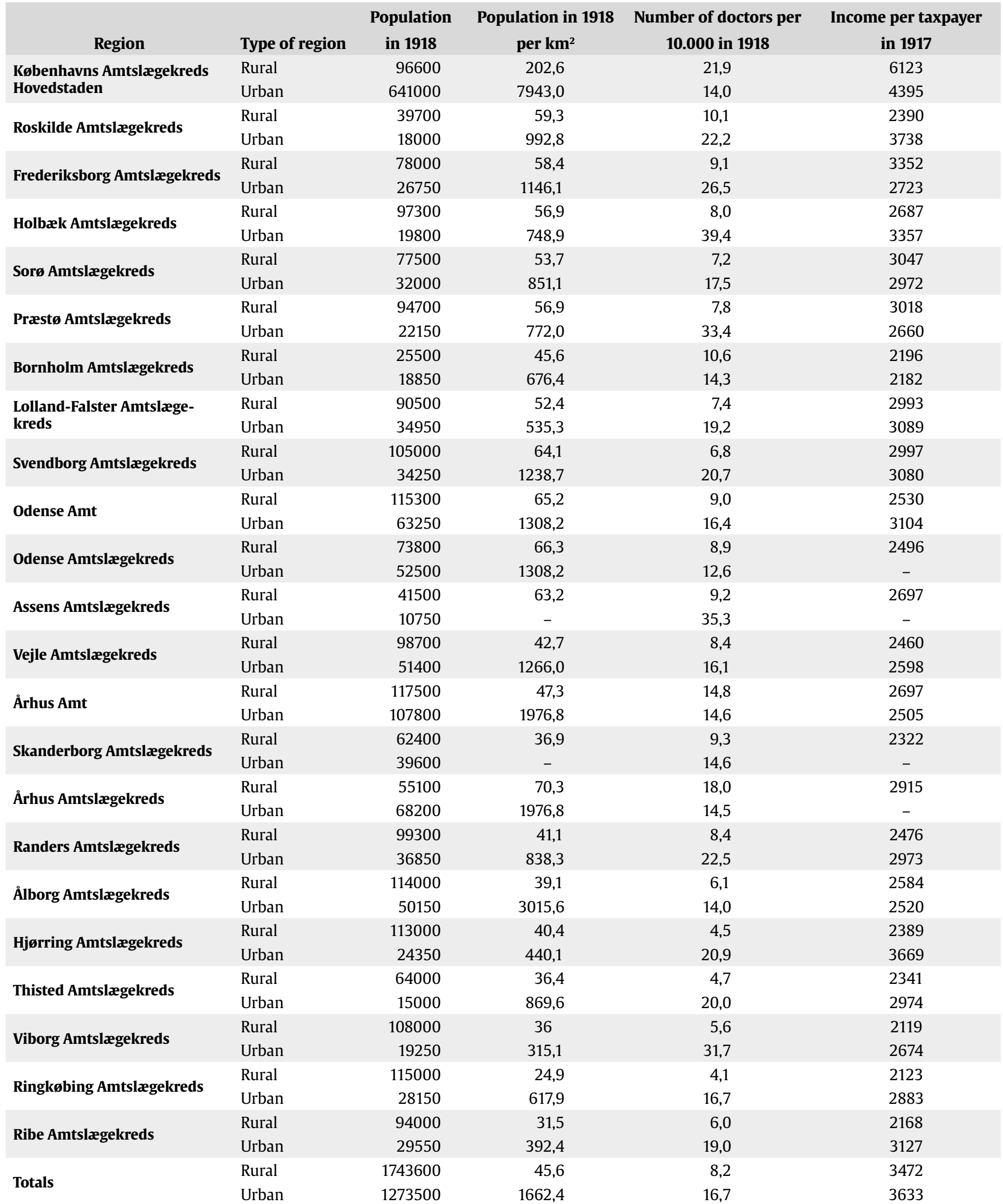

Sources: Medicinalberetning for den danske stat 1918; Statistics Denmark: census of 1916; Statistics Denmark: Ansættelserne til Indkomst- og Formueskatten for Skatteaaret 1917/1918.

*Only population and population density for 1918 are presented here as they did not change meaningfully between 1918 and 1920 


\section{Supplementary Table 3}

Statistical results of the linear mixed effects regression. Excess mortality per 10.000 was used as the dependent variable, and region was added as a random effect (see supplementary Table 1 and 2). In the full model the random effect explained $17,7 \%$ of the variance. The base model included rural vs urban, year and incidence. Each of the models 1 - 3 added a variable to the base model: model 1 investigates the association with doctors; model 2 the association with population density; and model 3 the association with income. A full-model incorporating each of these factors is also presented.

\begin{tabular}{|c|c|c|c|c|c|c|}
\hline \multirow[b]{2}{*}{ Variable } & \multicolumn{6}{|c|}{ Coefficient (Standard Error) } \\
\hline & Univariate & Base model & Model 1 & Model 2 & Model 3 & Full-model \\
\hline Rural vs. Urban & $5,8(2,0)^{* *}$ & $-1,7(2,2)$ & $-1,6(3,4)$ & $-1,5(3,3)$ & $0,06(2,3)$ & $1,3(5,1)$ \\
\hline \multicolumn{7}{|l|}{ Year } \\
\hline 1919 vs 1918 & $-1,4(2,6)$ & $11,7(3,2)^{* *}$ & $11,7(3,3)^{* *}$ & $11,7(3,3)^{* *}$ & $12,3(3,2)^{* *}$ & $12,2(3,2)^{* *}$ \\
\hline Influenza like incidence per 10.000 & $0,01(0,001)^{* *}$ & $0,01(0,002)^{* *}$ & $0,01(0,002)^{* *}$ & $\begin{array}{c}0,001 \\
(0,002)^{* *}\end{array}$ & $\begin{array}{c}0,001 \\
(0,002)^{* *}\end{array}$ & $0,01(0,002)^{* *}$ \\
\hline Number of doctors per 10.000 & $0,4(0,1)^{* *}$ & - & $-0,006(0,2)$ & - & - & $0,04(0,2)$ \\
\hline Population per square $\mathbf{k m}$ & $0,003(0,002)$ & - & - & $-0,001(0,002)$ & - & $-0,002(0,002)$ \\
\hline
\end{tabular}

*Statistically significant at the $\alpha<0,05$ level. ${ }^{* *}$ Statistically significant at the $\alpha<0,005$ level.

\section{Supplementary Table 4}

Statistical results of the linear mixed effects regression. Influenza-like incidence per 10.000 was used as the dependent variable, and region was added as a random effect (see supplementary Table 1 and 2). The base model included rural vs urban and year. In each of the models 1 - 3 added a variable to the base model: model 1 investigates the association with doctors; model 2 the association with population density; and model 3 the association with income. A full-model incorporating each of these factors is also presented.

\begin{tabular}{|c|c|c|c|c|c|c|}
\hline \multirow[b]{2}{*}{ Variables } & \multicolumn{6}{|c|}{ Coefficient (Standard Error) } \\
\hline & Univariate & Base model & Model 1 & Model 2 & Model 3 & Full-model \\
\hline Rural vs. Urban & $578,8(128,4$ & & $442,2(120,8)^{* *}$ & $667,5(107,7)^{* *}$ & $510,6(79,8)^{* *}$ & $468,0(175,0)^{* *}$ \\
\hline \multicolumn{7}{|l|}{ Year } \\
\hline 1919 vs 1918 & \multicolumn{2}{|c|}{$-1008,8(113,0)^{* *}$} & $-1008,8(89,4)^{* *}$ & $-1007,9(89,7)^{* *}$ & $-1008,8(88,5)^{* *}$ & $-1008,5(88.9)^{* *}$ \\
\hline Number of doctors per $\mathbf{1 0 . 0 0 0}$ & $30,5(7,6)^{* *}$ & - & $10,0(7,0)$ & - & - & $6,1(7,6)$ \\
\hline Population per square km & $0,3(0,1)^{*}$ & - & - & $-0,09(0,08)$ & - & $-0,03(0,09)$ \\
\hline Average income per tax-payer & $0,5(0,2)^{*}$ & - & - & - & $0,2(0,1)$ & $0,2(0,1)$ \\
\hline
\end{tabular}

*Statistically significant at the $\alpha<0,05$ level. ${ }^{* *}$ Statistically significant at the $\alpha<0,005$ level. 